\title{
RECEPTACIÓN Y DOGMÁTICA PENAL: ESTUDIO DE CASO EN EL CONTEXTO DEL SISTEMA PENAL ACUSATORIO COLOMBIANO
}

\section{Norberto Hernandez Jimenez ${ }^{1}$}

\section{Resumen}

El presente texto analiza a profundidad, una sentencia condenatoria por el delito de receptación, proferida por el Juzgado 30 Penal del Circuito de Bogotá (Colombia), en vigencia del sistema penal acusatorio consagrado en el Acto Legislativo 03 de 2002 y desarrollado en la Ley 906 de 2004. A través de un proceso de deconstrucción, se señalan los argumentos que tuvo en cuenta el despacho judicial para adoptar un fallo adverso a los intereses del sentenciado y las posibles falencias en que pudo incurrir con base en los lineamientos de la dogmática penal, así como la indebida valoración probatoria y la omisión de los principios constitucionales que sustentan el proceso penal.

Palabras clave: Receptación, sistema acusatorio, sentencia, pruebas, dogmática penal, debido proceso.

\section{INTRODUCCIÓN}

El 14 de diciembre de 2011, el Juzgado 30 Penal del Circuito de Bogotá, condenó a F.A.S.C.' como autor del delito de receptación, en concurso con uso de documento público falso, a la pena privativa de la libertad de 80 meses de prisión (Radicado: 110016000017201101928, Número interno: 142952). El sentenciado había sido capturado el 9 de marzo de 2011 tras comprobarse que la motocicleta en la que se transportaba se encontraba reportada como hurtada desde el 22 de agosto de 2010.

F.A.S.C. manifestó que observó la motocicleta (objeto material del delito) transitando por las calles de Bogotá, la cual portaba anuncios de venta, razón por la cual preguntó por su valor, llegando a un acuerdo con el vendedor, el cual comprendía el pago de una suma de dinero y la entrega de la motocicleta de propiedad de aquel (permuta), a favor del oferente, suscribiendo un contrato de compraventa en el centro comercial "Hayuelos" y perfeccionando la entrega, tanto de la cosa como del precio, el 11 de febrero de 2011, en dicho lugar.

Para condenarlo, el Juzgado tuvo en cuenta:

1. Que la motocicleta en la que se transportaba era hurtada y

\footnotetext{
${ }^{1}$ Doctorando en Derecho de la Universidad de los Andes. Coordinador del Grupo de Prisiones de la Universidad de los Andes y Conjuez del Tribunal Superior de Florencia (Caqueta) - Sala Penal.Email: n.hernandez29@uniandes.edu.co

${ }^{2}$ Se hace reserva del nombre con miras a proteger la intimidad del sentenciado e igualmente evitar una eventual re-victimización. Igual acontece con los demás nombres relacionados en la sentencia.
} 
2. Que la licencia de tránsito que exhibió era falsa ${ }^{3}$, concluyendo así que la posesión del rodante constituía delito y que la teoría exculpatoria, relacionada con el engaño que había padecido F.A.S.C. por parte del vendedor de la motocicleta, no tenía asidero, ya que el contrato de compraventa aportado, carece de fecha y huella, sin que fuera llevado ante Notario para su "registro" (página 5 de la sentencia).

Adicionalmente el cupo numérico de la cédula del vendedor, no existe (páginas 4 y 5 de la sentencia) y la compradora del rodante es la esposa del sentenciado (página 4 de la sentencia), construyendo con base en lo anterior, una prueba indiciaria para erigir un fallo adverso a los intereses de F.A.S.C.

El fallo de condena hace otras argumentaciones de fondo para restarle credibilidad al dicho del sentenciado - las cuales serán analizadas a lo largo de este texto -, con base en la siguiente pregunta de investigación: ¿Puede condenarse por el delito de receptación sin comprobarse el dolo? Para este efecto se analizarán las características del delito en cuestión y el contexto de este caso paradigmático, que es considerado interesante porqué muta -como en muchos casos-, la presunción de inocencia por una presunción de responsabilidad.

Lo anterior está directamente relacionado con la tensión entre sistema acusatorio y dogmática penal, que a voces de algunos litigantes, ha favorecido al primero, representado el decaimiento de la segunda ${ }^{4}$. Por esta razón, también se ofrecerán algunas reflexiones sobre la valoración probatoria dentro de un proceso de enjuiciamiento penal con tendencia acusatorio y las categorías de la dogmática jurídico - penal que deben superar un fallo condenatorio.

Finalmente, en lo que atañe al horizonte metodológico, para la elaboración de este artículo se recaudaron los pronunciamientos judiciales del presente proceso, así como los audios de las audiencias celebradas, con el objetivo de brindar una panorama lo más completo posible, dentro de la técnica de estudio de caso. Para confrontar la argumentación judicial, se recurrió tanto a otros pronunciamientos judiciales como a la doctrina dominante sobre el tema y a la regulación legal del delito de receptación en el ámbito internacional. No se realizaron entrevistas comoquiera que las posiciones de los actores, están plasmadas tanto en los audios como en la sentencia condenatoria.

\footnotetext{
${ }^{3}$ El Juzgado sostiene que la licencia exhibida se encontraba a nombre de "A.C.V.P." (página 4 y 6 de la sentencia), aún cuando en el acápite "Hechos" (página 1 de la sentencia) dijo que se encontraba a nombre de "L.F.M.L.", nombre este último que se compagina con la realidad procesal.

4 “2.2. ¿Desaparece la dogmática gracias a la adopción de un sistema acusatorio? Algunas voces se han alzado para señalar el fin de los días de la dogmática penal $(\mathrm{i})$, garantía fruto de siglos de pensamiento, gracias al advenimiento del sistema penal acusatorio. Quienes sostienen esta tesis entienden que en el nuevo proceso penal, lo que importa es la prueba y las capacidades histriónicas de los intervinientes." BERNATE (2005) p. 69.
} 


\section{LA RECEPTACIÓN}

La receptación es un delito contra la eficaz y recta impartición de justicia ${ }^{5}$ que consiste en la adquisición, posesión, conversión o transmisión de bienes muebles, que tengan su origen mediato o inmediato en un delito, o la realización de cualquier otro acto tendiente a ocultar o encubrir su origen ilícito, sin que el autor haya tomado parte en el delito primigenio (artículo 447 del Código Penal Colombiano) ${ }^{6}$.

A continuación se relacionan las características delito en cuestión ${ }^{7}$ :

1. Tipo de mera conducta;

2. Tipo de peligro;

3. Tipo de conducta instantânea;

4. Tipo mono-ofensivo.

Ahora bien, con independencia del sistema de enjuiciamiento penal que se adopte [mixto con tendencia inquisitivo (Ley 600 de 2000) o de corte acusatorio ${ }^{8}$ (Ley 906 de 2004)], para determinar la comisión de este delito, es indispensable establecer el conocimiento que tenía el autor, sobre la procedencia ilícita del objeto material del delito.

Al respecto, la Sala Penal del Tribunal Superior de Bogotá, en providencia del 21 de marzo de 2006, expresó ${ }^{9}$ :

El producto del delito son las cosas que provienen de su ejecución o sobre las cuales se ha realizado el quebrantamiento jurídico, como lo enseña Luis Carlos Pérez ${ }^{10}$. Pero resulta indispensable que el sujeto activo sepa que el objeto sobre el cual recae la conducta receptadora proviene de un delito y ese conocimiento tiene que ser indubitable, cierto y aún así, se realice uno de los verbos o varios de los descritos en este tipo penal. De suerte que no basta con ejecutar cualquiera de estas conductas para que se estructure la receptación, sino

\footnotetext{
5 “ ( ... ) con el delito de receptación se busca proteger la administración de justicia y evitar que sus autores disfruten del provecho de su delito o a procurar un beneficio al propio encubierto ( ... )” COLOMBIA, Rama Judicial del Poder Público, Tribunal Superior de Medellín -Sala Penal-, sentencia del 7 de junio de 2011, Radicación 05001-60-00206-2010-58044, Magistrado Ponente: Pio Nicolás Jaramillo Marín.

${ }^{6}$ En similar sentido los artículos 259 del Código Penal Alemán, 321-1 del Código Penal Francés y 456 Bis A del Código Penal Chileno, este último, con la excepción de la cláusula: "o no pudiendo menos que conocerlo" relacionada con el conocimiento sobre el origen ilícito del bien, que flexibiliza las exigencias probatorias sobre el dolo y se ubica en una frontera peligrosa entre este y la culpa.

${ }^{7}$ PABÓN (2012) p. 1065.

${ }^{8}$ Cfr. COLOMBIA, Rama Judicial del Poder Público, Corte Suprema de Justicia -Sala de Casación Penal-, providencia del 26 de octubre de 2007, Radicación 27608, Magistrado Ponente: Sigifredo Espinosa Pérez. Igualmente el salvamento parcial de voto de los Magistrados Sigifredo Espinosa Pérez, Augusto J. Ibáñez Guzmán, Julio Enrique Socha Salamanca y Javier Zapata Ortiz a la sentencia de la misma Corporación datada 17 de septiembre de 2007, Radicación 27336, Magistrado Ponente: Jorge Luis Quintero Milanés y Augusto J. Ibáñez Guzmán. Ver también sentencias de la misma Corporación datadas 30 de marzo de 2006, Radicación 24468, Magistrado Ponente: Edgar Lombana Trujillo que lo rotula como un "Sistema con tendencia acusatoria, no >>típico ni puro<<, sino específico para Colombia” y 6 de septiembre de 2007, Radicación 24786, Magistrado Ponente: Yesid Ramírez Bastidas. También en la sentencia C-454/06, Magistrado Ponente: Jaime Córdoba Triviño (Corte Constitucional de Colombia).

${ }^{9}$ Radicación: 1100160000132005096801 , Magistrado Ponente: Alberto González Gómez

${ }^{10}$ Derecho Penal, T. III Ed. Temis, 1985. p.149 (Cita propia de la providencia).
} vol. 08, nº. 04, Número Especial. Rio de Janeiro, 2015.pp. 2115-2138 
que es indispensable saber que el objeto material o el producto del delito que se adquiere, posee, convierte, transfiere u oculta es ilícito. Esta naturaleza del objeto material del tipo penal de receptación, aparece con claridad en el nuevo Código Penal cuando establece que la conducta debe recaer sobre "bienes que tengan su origen mediato e inmediato en un delito, o se realice cualquier otro acto para ocultar o encubrir su origen ilícito" (art. 447). $\underline{\text { Por }}$ manera que es necesario que en el proceso aparezca, indubitablemente, la prueba de que el sujeto agente tenía conocimiento de la ilícita procedencia del objeto receptado ..."

El autor citado anteriormente al respecto:

Ahora bien, el receptador debe tener conocimiento de que los objetos, armas o instrumentos que esconde o adquiere, o que ayuda a ocultar, provienen de un delito o sirvieron para ejecutarlo, elementos subjetivos que en el viejo régimen se destacaba con la frase a sabiendas, suprimida por ser una inútil reiteración de aquel elemento subjetivo. No es suficiente que quien adquiera las cosas o quien las enajena albergue dudas sobre el origen de ellas, sino que ha de estar seguro de su procedência. ${ }^{11}$ (Resaltado fuera del texto).

En similar sentido:

Ahora bien, para la estructuración del delito de receptación no es suficiente poseer, convertir o transferir bienes muebles o inmuebles que tengan su origen mediato o inmediato en un delito, puesto que la misma norma preceptúa que tales actos deben estar encaminados a "ocultar o encubrir su origen ilícito"; esto es, quien detenta el bien o realiza con él actos dispositivos tendientes a conseguir el fin previsto en la norma, debe conocer la ilicitud del origen.

Entonces, a efectos de atribuir la responsabilidad penal a título de dolo -pues no es conducta de naturaleza culposa- debió la fiscalía demostrar que la procesada conocía el origen del automotor pues de otro modo, esto es, con ignorancia sobre tal supuesto, imposible resulta referir para afirmar, la señalada responsabilidad. ${ }^{12}$ (Resaltado fuera del texto).

En consecuencia, para la imputación subjetiva de este delito, debe no solo acreditarse el conocimiento de los hechos constitutivos de la infracción penal, sino la voluntad para su realización (aspectos cognitivo y volitivo), por tratarse de un delito doloso, que no admite la modalidad culposa ni mucho menos preterintencional. Se insiste en cuanto "el dolo está compuesto en este caso, por el conocimiento del hecho anterior contra los bienes, que ha dado efectos estimables económicamente, y el querer aprovecharse de estos efectos" ${ }^{13}$.

\section{CONOCIMIENTO PARA CONDENAR}

Establecía el artículo 232 de la Ley 600 de 2000, que para condenar se requería certeza sobre la conducta punible y la responsabilidad del procesado. La certeza constituye un íntimo convencimiento sobre un determinado objeto del conocimiento, negativo o positivo, obtenida como resultado de una elaboración mental, siempre fundamentada en elementos objetivos, que no son otros que los elementos de convicción obrantes en el proceso y las reglas de la sana crítica, para llegar a un criterio de verdad, partiendo de una base objetiva y naturalmente constatable.

\footnotetext{
${ }^{11}$ Ibídem, p.414 (Cita propia de la providencia).

${ }^{12}$ COLOMBIA, Rama Judicial del Poder Público, Tribunal Superior de Bogotá -Sala Penal -, providencia del 9 de noviembre de 2005, Radicación: S 040 -2005- 02208 - 01, Magistrada Ponente: María Del Rosario González De Lemos

${ }^{13}$ BUSTOS (1986) p. 250. Para un estudio pormenorizado sobre el dolo - en abstracto -, se remite al lector al capítulo "El dolo en el Código penal de 2000" de autoría del Profesor Ricardo Posada Maya (2008) pp. 1-73.
} vol. 08, nº. 04, Número Especial. Rio de Janeiro, 2015.pp. 2115-2138 
Así, para condenar en el proceso mixto con tendencia inquisitiva ${ }^{14}$ :

1. La prueba tiene que existir en el proceso, objetivamente;

2. Tiene que ser prueba cualificada como objetivamente idónea para producir certeza. Esto es, que quien la aprecie pueda adquirir el convencimiento pleno de que ha existido una conducta punible y que el sindicado es responsable;

3. Referir la capacidad para adquirir certeza a una persona del promedio;

4. Como consecuencia de la certeza, tiene que estar descartada la duda.

Esto escenario fluctuó con la entrada en vigencia de la Ley 906 de 2004, que en su artículo 381 exige para condenar, el conocimiento más allá de toda duda razonable acerca del delito y la responsabilidad penal del acusado. Este grado de conocimiento - importado del sistema anglosajón ${ }^{15}$ y expandido conjuntamente con el sistema acusatorio en Latinoamérica ${ }^{16}$-, pretende flexibilizar las exigencias para el ejercicio del ius puniendi y restringir (no de manera absoluta) la aplicación del principio indubio pro reo, debiendo acreditarse en todo caso, las categorías propias de la dogmática jurídico - penal.

Sobre esta variación legal, la jurisprudencia de la Sala de Casación Penal de la Corte Suprema de Justicia, ha entendido que:

En efecto, la convicción sobre la responsabilidad del procesado "más allá de toda duda", corresponde a un estadio del conocimiento propio de la certeza racional ${ }^{17} \mathrm{y}$, por tanto, relativa, dado que la certeza absoluta resulta imposible desde la perspectiva de la gnoseología en el ámbito de las humanidades e inclusive en la relación sujeto que aprehende y objeto aprehendido.

En consecuencia, sólo cuando no se arriba a dicha certeza relativa de índole racional ante la presencia de dudas sobre la materialidad y existencia del delito investigado o sobre la responsabilidad del acusado, siempre que, en todo caso, dichas dudas tengan entidad y suficiencia como para crear incertidumbre sobre tales aspectos que tienen que ser debidamente acreditados con medios de prueba reales y posibles en cada caso concreto, no con elementos de convicción ideales o imposibles, ahí, en tal momento, es posible acudir a la aplicación del principio in dubio pro reo, esto es, resolver la vacilación probatoria en punto de la demostración de la verdad, a favor del acusado.

Así las cosas, no resulta conforme con la teoría del conocimiento exigir que la demostración de la conducta humana objeto de investigación sea absoluta, pues ello siempre será, como ya se dijo, un ideal imposible de alcanzar, como que resulta frecuente que variados aspectos del acontecer que constituyó la génesis de un proceso penal no resulten cabalmente acreditados, caso en el cual, si tales detalles son nimios o intrascendentes frente a la información probatoria ponderada en conjunto, se habrá conseguido la certeza racional, más allá de toda duda, requerida para proferir fallo de condena.

Por el contrario, si aspectos sustanciales sobre la materialidad del delito o la responsabilidad del acusado no consiguen su demostración directa o indirecta al valorar el cuadro conjunto de pruebas, se impone constitucional y legalmente aplicar el referido principio de resolución de la duda a favor del incriminando, el cual a la postre, también se encuentra reconocido en la

\footnotetext{
${ }^{14}$ ARENAS (1996) p. 602.

${ }^{15}$ BAYTELMAN y DUCE (2005) p. 75. También PARRA (2009) p. 821.

${ }^{16}$ El artículo 340 del Código de Procedimiento Penal Chileno contiene la misma cláusula, para citar un ejemplo.

${ }^{17}$ En este sentido sentencia C-609 del 13 de noviembre de 1999 (Cita propia de la providencia).
} vol. 08, nº. 04, Número Especial. Rio de Janeiro, 2015.pp. 2115-2138 
normativa internacional como pilar esencial del debido proceso y de las garantías judiciales. (Sentencia del 5 de diciembre de 2007, Radicación 28432, Magistrada Ponente: Maria del Rosario González de Lemos).

Ahora bien, el profesor Parra Quijano ${ }^{18}$ considera que no era necesario incluir en Colombia ni en Chile la cláusula en comento, en la medida que los jueces son abogados y las pruebas se valoran de conformidad con las reglas de la sana crítica. Sin embargo, con base en la cita jurisprudencial que antecede, se observa cómo la Judicatura ha entendido que en el sistema de enjuiciamiento penal con tendencia acusatorio, el grado de conocimiento es inferior al exigido en el proceso mixto con tendencia inquisitivo. En todo caso, esto no significa eliminar la duda ni el principio indubio pro reo, que tienen rango constitucional ${ }^{19}$ y que deben ser aplicados prevalentemente, a pesar de que en la práctica, no ocurra de esta manera.

\section{VALORACIÓN PROBATORIA}

Una vez analizados los aspectos preliminares concernientes al delito y al grado de conocimiento para condenar, en el presente acápite se señalarán los argumentos que tuvo en cuenta el Juzgado 30 Penal del Circuito de Bogotá para edificar la sentencia condenatoria, indicando las deficiencias en materia de valoración probatoria y las alternativas con que contaba, las cuales hubieran modificado su decisión.

\section{La inexistencia del Contrato de compraventa}

Según la Jueza, el contrato fue creado como fachada, construyendo así una estrategia para ocultar el origen ilegítimo de la motocicleta. En este aspecto es importante resaltar que la juzgadora de instancia no tiene en cuenta, ni siquiera, las estipulaciones probatorias ${ }^{20}$ realizadas por las partes, donde se establece que el contrato existe y que el mismo no fue realizado por la esposa de F.A.S.C. (Estipulación probatoria № 5) lo que constituye, bajo la técnica casacional, un falso juicio de existencia por omisión ${ }^{21}$.

\footnotetext{
18 (2009) p. 835.

${ }^{19}$ Artículo 29 Constitución Política de Colombia

20 "De conformidad con el artículo 356.4, las partes pueden hacer estipulaciones probatorias, entendiéndose por tales, a voces del parágrafo de la disposición, "los acuerdos celebrados entre la Fiscalía y la defensa para aceptar como probados alguno o algu nos de los hechos o sus circunstancias". La potestad legal, entonces, apunta a que por acuerdo entre las partes, no hay lugar a debatir en el juicio algún hecho o sus circunstancias; por tanto, el tema de responsabilidad no puede ser estipulado y, por ello, se impone probarlo en el juzgamiento.

Una estipulación es un convenio, un acuerdo que, en este caso, comporta que las partes dan por demostrados, por verificados, los aspectos reseñados taxativamente en la norma, de lo cual surge que los mismos quedan excluidos de someterlos al sistema probatorio dentro del juicio, razón por la cual la estipulación misma, sin más aditamentos, constituye la prueba del hecho o circunstancia, de donde deriva que no existe la carga de anexar elemento alguno para respaldar la estipulación, por lo cual se tiene que si las partes tuvieron a bien aportar algún soporte en respaldo del pacto, el mismo no tiene incidencia alguna, pues no puede probar ni menos ni más de lo acordado." COLOMBIA, Rama Judicial del Poder Público, Corte Suprema de Justicia -Sala de Casación Penal-, providencia del 6 de febrero de 2013, Radicación38975, Magistrado Ponente: José Luis Barceló Camacho.
}

21 “( ... ) acontece cuando el juzgador no estudia una prueba obrante en el proceso ( . . . ) HERNÁNDEZ (2010) p. 12. vol. 08, nº. 04, Número Especial. Rio de Janeiro, 2015.pp. 2115-2138 
En la citada estipulación probatoria la Jueza hace la siguiente aclaración:

Jueza: Haber Doctor, perdóneme le pido desmenuzar un poquito mejor esa situación, ¿isí?, Fiscal: si, Jueza: el, la estipulación es sobre el hecho del contrato de compraventa de la moto, Fiscal: sobre la la.

Jueza: El acto de compraventa, ¿sí?,

Fiscal: si.

Jueza: de promesa o de compraventa.

Fiscal: si.

Jueza: de compraventa.

Fiscal: de, de, si de compraventa, de adquisición.

Jueza: de la moto.

Fiscal: de adquisición de la motocicleta.

Jueza: de adquisición de la motocicleta por parte del processado.

Fiscal: si.

Jueza: Bueno, ¿qué hechos se encuentran ahí Doctor?, perdóneme.

Fiscal: Los hechos que se encuentran en ese documento es que el procesado no suscribe como comprador, suscribe la señora J.P.S., quien es la esposa del procesado. La prueba se refiere a quien aparece, escribiendo o suscribiendo como A.O., quien es la persona que ...

Jueza: que vende.

Fiscal: que vende o entrega la moto, eh, esa letra de A.O. suscrita sobre ese documento, no es letra de J.P.S., es decir, se descarta que ella misma haya sido la que haya colocado el nombre como de un vendedor, del vendedor" ${ }^{22}$

De lo anterior se puede establecer que existió un contrato de compraventa, lo cual decide objetar de facto la juzgadora en su motivación, aunado a que la posible falsedad del mismo fue descartada con un experticio igualmente estipulado, sin que se pueda edificar con base en este argumento, la autoría en el delito contra la eficaz y recta impartición de justicia. Por lo menos existiría una duda sobre la existencia del negocio jurídico que la funcionaria decidió omitir y que al pasar por alto, le permitió construir un fallo de condena.

Incluso, de la valoración de esta prueba, se extracta que el comprador de la motocicleta, no es el individuo convocado a juicio, sino su esposa, como lo afirma la funcionara en su sentencia (página 4 de la sentencia). Aunado a lo anterior, dentro de las nociones básicas del derecho civil, debe advertirse que el contrato de compraventa existe siempre y cuando concurra acuerdo entre la cosa y el precio, a diferencia de los cuestionamientos que hace la juzgadora, siguiendo en gran medida los argumentos ofrecidos por el investigador del C.T.I. ${ }^{23}$

\footnotetext{
${ }^{22}$ Record 15:12 a 16:26 (audiencia de juicio oral)

${ }^{23}$ Estas siglas corresponden al Cuerpo Técnico de Investigaciones, que es un organismo adscrito a la Fiscalia General de la Nación. A propósito del registro del contrato de compraventa de la motocicleta, para efectos de su tradición, en el transcurso del juicio oral, la jueza le pregunta al investigador: "¿Por qué tendría que radicarse?" Record 37:18 a 37:19 (audiencia de juicio oral). Al respecto es preciso mencionar que el investigador del C.T.I. fue citado acorde con lo normado en el artículo 399 del Código de Procedimiento Penal y no como un testigo experto en materia de derecho civil para acreditar el título y el modo frente al negocio jurídico inherente a la motocicleta objeto del delito, sin embargo en su interrogatorio, la Jueza le otorga estas calidades, al punto que le formula preguntas relacionadas con este tópico.
} 
Igualmente, acudiendo a los mismos criterios privatistas, con base en los cuales se reprocha la falta de registro del mismo, debe señalarse que esta situación es de común ocurrencia y no vicia la negociación (título) sino solamente la tradición (modo) del bien.

\section{El conocimiento de la procedencia de la motocicleta por parte de F.A.S.C., por haber llamado a quien aparece como propietario en la licencia de tránsito}

F.A.S.C. nunca negó haber llamado al propietario de la motocicleta, lo que corrobora el investigador de la Fiscalía. Sin embargo, la Jueza tergiversa la prueba para erigir el conocimiento de aquel, sobre el origen ilícito de la misma (página 6 de la sentencia), cuando esta comunicación se dio con posterioridad a su captura, incurriendo así en un Falso juicio de identidad ${ }^{24}$.

Así refiere el investigador del C.T.I.:

Ubiqué al propietario de la motocicleta original de placas XXX que es un señor de apellido XXX, eh, este señor en la entrevista es muy claro en señalar que la motocicleta de placas XXX estaba en su poder, que nunca la había vendido, pero que había recibido una llamada de un señor que había dicho llamarse F.A.S.C. quien le manifestó que tenía en su poder una motocicleta de placas XXX a lo que el señor XXX le manifestó que no era posible ya que el tenía esa motocicleta en su poder, ya después de insistir F.A.S.C., esta persona no le volvió a contestar el número del teléfono por esa situación, porque él lo llamaba y le manifestaba que necesitaba ver la otra motocicleta. ${ }^{25}$

Claro, con posterioridad al negocio jurídico celebrado con el vendedor y tras su captura, F.A.S.C. supo que la motocicleta era hurtada, pero esto no constituye el delito de receptación, ya que ese conocimiento debió ser antecedente a la adquisición de la moto y no posterior, como se evidencia en el presente caso.

A propósito de la captura, nótese que F.A.S.C. se presentó voluntariamente para que dentro del operativo fuera revisada la moto y los documentos de la misma ${ }^{26}$.

Ya la policía había pasado revisando todas las motos y la mía no me la revisaron, yo le dije a un policía, vea, lo que pasa es que yo me tengo que ir porqué tengo mucho trabajo, necesito saber si me puedo ir porqué a mi no me han revisado la moto, me dice permítame los papeles, yo le entrego la tarjeta de propiedad (...) le entregué todos los papeles, ellos procedieron a revisar la moto $(\ldots) .{ }^{27}$

La misma situación se vislumbra en relación con la licencia de tránsito falsa que portaba en el momento de su captura, desconociendo aquel la ilicitud de la misma, al haber sido entregada en virtud del negocio jurídico multicitado.

\footnotetext{
${ }^{24}$ “ ( ... ) se traduce en la tergiversación del contenido fáctico de la prueba, es decir, le otorga conclusiones que no se desprenden de ella; asimismo por fraccionamiento de aquella, omitiendo su valoración integral (... )" HERNÁNDEZ (2010) p. 12.

${ }^{25}$ Record 47:53 a 48:53 (audiencia de juicio oral)

${ }^{26}$ Cfr. Record 01:44:09 a 01:45:05 (audiencia de juicio oral)

${ }^{27}$ Record 01:45:07 a 01:45:42 (audiencia de juicio oral)
} vol. 08, nº. 04, Número Especial. Rio de Janeiro, 2015.pp. 2115-2138 
Para culminar este acápite sea preciso señalar, como la Jueza derrumba toda la teoría del delito construida a través de varios años, bastándole con el análisis de tipicidad (errado) de la conducta y omitiendo el principio de lesividad "como legitimador y limitador del poder sancionador del Estado" 28 y su corolario la antijuridicidad (artículo 11 del Código Penal), así como la culpabilidad (artículo 12 del Código Penal), que con base en el raciocinio de su providencia, se deberán inferir lógicamente con base en las "reglas de la lógica y la sana crítica”. Incluso se desconoce cuál fue el verbo rector judicializado en este caso en particular.

Se insiste, si no hay lesividad en la conducta que supuestamente resultó típica, debía de todas formas absolverse a F.A.S.C. de los cargos endilgados por el delegado de la Fiscalía General de la Nación en pretérita oportunidad. Lo mismo ocurre, se insiste, con la culpabilidad ${ }^{29}$ ya que la juzgadora de instancia no examina si el perfil de F.A.S.C. ${ }^{30}$ se corresponde con el fin de protección de la norma penal consagrada en el artículo 447 del Código Penal, obviando en su decisión que "No se trata sólo, en consecuencia, como lo enfocan las teorías tradicionales de la culpabilidad, de que el individuo tenga que acreditar que se encuentre en alguno de los supuestos de inculpabilidad establecidos en la ley, sino, al revés, de que el Estado demuestre que, en su condición de Estado de derecho social y democrático, esté en condiciones de exigirle a ese individuo concreto el cumplimiento de las normas jurídicas que al fin y al cabo no son sino sus propias normas (del Estado)"31

Siguiendo con el razonamiento del Tribunal ${ }^{32}$, se observa que F.A.S.C. ostentaba un arraigo social, familiar y personal, ya que tenía un hogar, fruto del cual nació una niña, al igual que poseía un empleo como mensajero. Con base en lo anterior es dable preguntar: ¿Se actualiza en este caso el fin perseguido por la norma?:

\footnotetext{
${ }^{28}$ COLOMBIA, Rama Judicial del Poder Público, Corte Suprema de Justicia - Sala de Casación Penal-, providencia del 17 de agosto de 2011, Radicación 35978, Magistrado Ponente: Fernando Alberto Castro Caballero.

29 "Hoy resulta mucho más coherente sostener que la culpabilidad constituye una teoría aparte que ha de dotar de contenido a la necesaria respuesta que ha de dar la teoría penal a la pregunta de por qué se le ha de exigir responsabilidad o si se le puede exigir responsabilidad penal a esa persona concreta por la comisión del injusto en el cual ha sido identificado como autor" BUSTOS y HORMAZÁBAL (2004) p. 68.

${ }^{30}$ En un caso similar, la Sala Penal del Tribunal Superior de Bogotá, refirió: "De otra parte, como el delito de receptación fue establecido por el legislador como forma de golpear y controlar las estructuras delicuenciales en el entendido de que luego de cometer el acto ilícito, generalmente de hurto, requerían el concurso de otros sujetos que sin colaborar en la ejecución del primer delito estuvieran dispuestos a ayudar para el ocultamiento o encubrimiento del origen, es necesario examinar si el perfil de la procesada se adecua a esa connotación."

"Según da cuenta la actuación la procesada no detenta el perfil de delincuente pues se trata de una docente escalafonada en el grado 14, esto es, el más alto dentro de las categorías de la educación básica y media, madre de tres hijos de los cuales se conocen datos de dos, una odontóloga y otro a punto de culminar estudios en derecho."

"Entonces, las características de señora trabajadora, docente en jornada diurna y nocturna, no encajan en el esquema del delincuente mentiroso, carente de principios, enfrentado a las normas sociales dispuesto a quebrantar principios y valores a cambio de exhibir lo que realmente no le corresponde."

"Entonces como la fiscalía fue incapaz de demostrar el conocimiento que M.M.A. podía tener sobre el origen ilícito del bien, mismo que no se podía apreciar a simple vista pues los sistemas de identificación del automotor eran totalmente originales y sólo un experto podía notar la irregularidad de la placa, se debe confirmar la decisión de la A quo." Providencia del 9 de noviembre de 2005, Radicación: S 040 -2005- 02208 - 01, Magistrada Ponente: María Del Rosario González De Lemos. (Resaltado fuera del texto).

${ }^{31}$ BUSTOS y HORMAZÁBAL (2004) p. 126.

${ }^{32}$ Providencia del 9 de noviembre de 2005, Radicación: S 040 -2005- 02208 (ya relacionada).
} vol. 08, nº. 04, Número Especial. Rio de Janeiro, 2015.pp. 2115-2138 
Como forma de golpear y controlar las estructuras delicuenciales en el entendido de que luego de cometer el acto ilícito, generalmente de hurto, requerían el concurso de otros sujetos que sin colaborar en la ejecución del primer delito estuvieran dispuestos a ayudar para el ocultamiento o encubrimiento del origen. ¿̇e examinó por la jueza el perfil del procesado para determinar si se adecuaba a esa connotación?

Con base en lo anterior se considera que en el presente caso no existe encubrimiento real ${ }^{133}$, al punto que F.A.S.C. ingenuamente se movilizaba en la motocicleta que resultó ser hurtada. La lógica no enseña eso, como se abordará más adelante en el acápite correspondiente a la prueba indiciaria (infra 4.), ya que para el ocultamiento del objeto material del delito contra el patrimonio económico, el receptador no se expone con el mismo por las calles de la ciudad, sino que pretende ocultarlo o separarlo por partes para obtener un provecho con la comercialización de las mismas.

\section{Análisis de la prueba testimonial}

Para apreciar el testimonio, el juzgador ha de estarse a los dispuesto en el artículo 404 del Código de Procedimiento Penal, esto es, tener en cuenta los principios técnico - científicos sobre la percepción y la memoria y, especialmente, lo relativo a la naturaleza del objeto percibido, al estado de sanidad del sentido o sentidos por los cuales se tuvo la percepción, las circunstancias de lugar, tiempo y modo en que percibió los procesos de rememoración, su comportamiento durante el interrogatorio y el contrainterrogatorio, la forma de sus respuestas y su personalidad.

A pesar de lo anterior, en el fallo objeto de estudio, se optó simplemente por no otorgarle credibilidad a los testigos de descargos, con el argumento principal de la inexistencia del contrato, que como se anotó de manera precedente, se encuentra acreditado, omitiendo el análisis que impone la norma jurídica citada, e incluso se termina condenando únicamente con lo manifestado por el investigador del C.T.I., quien solo contribuye con el esclarecimiento de las circunstancias inherentes a la investigación y no a la acreditación del dolo de F.A.S.C., en las conductas punibles endilgadas.

De las declaraciones de F.A.S.C. y de su esposa, acorde con la teoría finalista, se puede encontrar que en este caso se da el fenómeno de la atipicidad ${ }^{34}$ por carencia de dolo en las conductas endilgadas en la acusación por

\footnotetext{
${ }^{33}$ A diferencia del encubrimiento personal, en el que se oculta al autor del delito, en el encubrimiento real se ocultan o comercializan los objetos hurtados “ ( ... ) ayudando, así, no sólo a que el ladrón eluda la acción de las autoridades, o haciendo más difícil la labor de estas, sino también contribuyendo a la consumación del delito al hacer que el agente del mismo consiga plenamente sus fines y se agote, así, la lesión al derecho patrimonial afectado” COLOMBIA, Rama Judicial del Poder Público, Corte Suprema de Justicia -Sala de Casación Penal-, providencia del 4 de junio de 1982, Radicación: 26836, Magistrado Ponente: Luis Enrique Romero Soto.

34 "Fenómeno en virtud del cual un cierto quehacer del hombre, aparentemente punible, no se adecua a ningún tipo legal y, por ende, no es susceptible de sanción alguna en el ámbito del derecho penal” REYES (1989) p. 3. 
parte del delegado de la Fiscalía General de la Nación, máxime cuando las declaraciones de descargos, no fueron tachadas de falsas ni desacreditadas en el transcurso del juicio oral.

Aquellas son consistentes en señalar las circunstancias propias del negocio jurídico y el engaño en que cayeron frente a las argucias del vendedor para, él sí, ocultar la procedencia ilícita de la motocicleta vendida. Negocio jurídico en virtud del cual se entregó la licencia de tránsito falsa hallada en poder de F.A.S.C., sin que este tuviera conocimiento de su ilicitud de manera antecedente a la captura.

\section{Análisis de la prueba indiciaria}

Comoquiera que el dolo es ciertamente imposible de aportar al proceso con base en una foto que demuestre la conciencia del agente en la comisión del delito y su voluntad de infringir la ley penal, la Jueza apoyó en gran medida su fallo de condena, a partir de la prueba indiciaria. Pero, ifue una construcción afortunada la que hizo aquella para condenar a F.A.S.C.? ¿Cumplió con los requisitos establecidos en la jurisprudencia y la doctrina para este efecto?

Nótese como el indicio adquiere su calidad de prueba luego de hacer uso del ejercicio lógico jurídico, a través del cual, de un hecho probado se infiere la existencia de otro hecho, con la guía de los parámetros de la sana crítica, acudiendo a los principios de la lógica, las máximas de la experiencia y los aportes científicos, que no permiten en el presente caso llegar a la misma conclusión que la que expresó la Jueza, con exclusión de otros posibles resultados de una inferencia lógica ${ }^{35}$.

Dentro del discurso retórico de la juzgadora se insiste en señalar las "reglas de la lógica y la experiencia" para efectos de condenar a F.A.S.C. con base en los indicios, sin embargo omite señalar de cuáles de estas reglas se valió para llegar a su conclusión de condena. Estas deben ser generales y no personalísimas del juzgador, so pena de incurrir en arbitrariedad judicial ${ }^{36}$.

\footnotetext{
35 "La valoración integral del indicio exige al juez la contemplación de todas las hipótesis confirmantes e invalidantes de la deducción, pues rechazar cualquiera de las posibilidades lógicas que puede ofrecer un hecho indicador, desestimándolo expresa o tácitamente sólo porque el juez ya tiene sus propias conclusiones sin atención a un juicio lógico integral, es alentar un exceso de omnipotencia contrario al razonable acto de soberanía judicial en la evaluación de la prueba, que consiste precisamente en el ejercicio de una discrecionalidad reglada en la valoración probatoria." COLOMBIA, Rama Judicial del Poder Público, Corte Suprema de Justicia -Sala de Casación Penal- sentencia del 8 de julio de 2003, Radicación 18.583, citada en sentencia de la misma Corporación datada el 13 de septiembre de 2006, Radicación 23.251, Magistrado Ponente: Álvaro Orlando Pérez Pinzón, en donde también se citó la sentencia del 8 de mayo de 1997, Radicación 9.858 en cuyo aparte relacionado con el tema expresa: “( ...) en ejercicio de la discrecionalidad reglada en la valoración probatoria realiza el juez, quien después de contemplar todas las hipótesis confirmantes e infirmantes de la deducción establece jerarquías según el grado de aproximación a la certeza que brinde el indicio, sin que ello pueda confundirse con una tarifa de valoración preestablecida por el legislador." (Resaltado fuera del texto).

${ }^{36}$ Nótese por ejemplo, en un caso fallado por el Juzgado de Letras y Garantía de Pucón (6 de junio de 2003), como el Despacho Judicial, a pesar de existir aceptación de responsabilidad, hace la siguiente argumentación: "Incluso más respecto del conocimiento del origen de las cosas, que es un requisito del tipo, también se cumple por ambos requeridos. Es así como el requerido G., al comprar las especies del requerido N., que es una persona sin oficio y de escasísimos recursos, no pudo sino darse cuenta del origen ilícito de los mismos, ya que no cabía explicación lógica que llevara a concluir que aquel que se las vendió, las tenía en su poder por vol. 08, nº. 04, Número Especial. Rio de Janeiro, 2015.pp. 2115-2138 2125
} 
En el campo investigativo, Gorphe consagra la siguiente clasificación enunciativa ${ }^{37}$ :

1. Indicios de presencia. Por ejemplo haber sido la última persona vista en compañía de la víctima o haber encontrado sus huellas dactilares en el teatro de los acontecimientos. También, haber sido capturado cerca a este lugar y encontrar en su poder objetos de la víctima, etc.;

2. Indicios de participación en el delito. Por ejemplo las manchas de sangre, las huellas dactilares en las armas, las manchas de fluidos corporales. También los elementos probatorios de propiedad del acusado encontrados en el lugar de los hechos o las manchas de sangre correspondiente a la víctima, en su vestimenta, etc.;

3. Indicios de personalidad. Por ejemplo su conducta, sus antecedentes judiciales, su temperamento, sus reacciones, su disposición delictiva, etc.;

4. Indicios de móvil delictivo. Por ejemplo el interés económico, sexual, político, la satisfacción de una pasión, de un deseo, de una venganza, el arrebato en una disputa, etc.;

5. Indicios de actitud sospechosa. Por ejemplo el cambio de residencia, el alejarse del lugar donde se cometió el delito, fugarse después de estar detenido (lo cual es cuestionable por las condiciones de hacinamiento carcelario), preparar falsas pruebas, etc.

\section{Indicios de falsa justificación. Por ejemplo cuando se desvirtúa la coartada}

Ninguno de estos fue tenido en cuenta por la Jueza en su fallo condenatorio. Adicionalmente, no señala la funcionaria judicial, cual es su construcción lógica ni a partir de que hechos indicadores construye el ejercicio intelectivo, ya que no expresa cuales son estos últimos. Tampoco cual es la regla de la experiencia ni mucho menos la conexión entre el hecho indicador (desconocido en el presente caso) y el hecho indicado (igualmente desconocido). ¿Será labor de las partes y de la sociedad en general hacer una inferencia lógica para llegar al entendimiento del fallo de instancia?

De antaño, nuestro Tribunal de Casación ha expresado sobre las reglas de la experiencia y la construcción del indicio ${ }^{38}$ :

Cuando la regla de experiencia se cumple con mucha frecuencia, el indicio es grave. Si la regla de experiencia se cumple con poca frecuencia, el indicio es leve. El indicio es grave ha dicho la Corte, cuando entre el hecho que se conoce (indicante, indicador o causal) y el

haberlas comprado en algún negocio establecido". La regla de la lógica a la que acudió la funcionaria se muestra diáfana: N. no tenía recursos para adquirir los bienes incautados que le vendía a G. (la inferencia lógica estaría comprendida entre los indicios de personalidad y de móvil delictivo). No ocurre lo mismo en el caso bajo análisis, donde el sentenciado contaba con un empleo e incluso un rodante que permutó para acceder a la motocicleta que resultó ser hurtada.

${ }^{37}$ Martínez (2006) pp.399-402.

${ }^{38}$ COLOMBIA, Rama Judicial del Poder Público, Corte Suprema de Justicia -Sala de Casación Penal-, providencia del 26 de mayo de 1971, Magistrado Ponente: Luis Carlos Pérez y providencia del 27 de julio de 1982, Magistrado Ponente: Alfonso Reyes Echandía. 
hecho que se quiere conocer (consecuencial o indicado) referente al delito o a la responsabilidad del agente, media un nexo probable, creado por la dependencia inmediata con el fenómeno principal, por una cadena causal fuertemente acentuada por la exterioridad reveladora de su composición. Probable es lo que puede ocurrir fácilmente, pues se funda en razones serias y estables a diferencia de lo posible que puede tomar fuerza o no, ejecutarse o confirmarse a un simple proyecto. El juicio de responsabilidad depende pues del grado en que puedan sucederse racionalmente los actos y los acontecimientos.

Ahora bien, argumenta la funcionaria que F.A.S.C. es una persona experimentada en la compra de motocicletas y se le reprocha la cautela que debía tenerse en el negocio. Pero, ¿Será lógico que un mensajero, que utiliza como medio de transporte una motocicleta, la adquiera de manera irregular para ejercer su labor cotidiana? ¿Será lógico que una persona que sabe que la motocicleta es hurtada, se movilice por la ciudad tranquilamente, ejerciendo su labor de mensajería? ¿Será lógico que conociendo la procedencia de la misma, al encontrase en un retén le diga al policía que se la revise, en vez de dejar la moto y huir? Por otra parte ¿Será que un mensajero de una firma de abogados no requiere de la escuela de leyes para obtener los conocimientos propios de la profesión y en especial de las ciencias penales, determinando así las categorías dogmáticas de cada comportamiento cotidiano $?^{39}$ En definitiva ¿Serán estas reglas de la experiencia?

¿No será más lógico que el receptador pretenda salir del objeto a través de la compraventa -como lo hizo el vendedor - o que lo separe por partes para proceder a la venta de las mismas? ¿No será importante analizar el perfil del acusado -como lo indica el Tribunal Superior de Bogotá- para construir el juicio de reproche penal?

En este sentido se observa que la Fiscalía no logró descartar los siguientes eventos:

1. Que la compra de la motocicleta por parte de F.A.S.C. era un buen negocio ${ }^{40}$;

2. Que ese buen negocio lo hizo actuar impulsivamente;

3. Que ese impulso lo conllevó a un comportamiento poco diligente;

4. Que F.A.S.C. fue engañado y

5. Que F.A.S.C.

Solo se enteró de la procedencia ilícita del rodante con ocasión de su captura, circunstancias todas estas que deben descartarse para despejar las dudas y la inevitable aplicación del principio indubio pro reo, con mayor razón cuando se recurre a la prueba de indicios ${ }^{41}$, misma que en este caso resultó sumamente frágil e imposible de estructurar en el sentido pretendido por la Fiscalía General de la Nación y convalidada por la Jueza.

\footnotetext{
${ }^{39}$ La jueza hace especial énfasis en esta situación (Página 6 de la sentencia condenatoria).

${ }^{40}$ Cfr. Record 01:41:53 a 01:42:27 (audiencia de juicio oral)

41 "Sabido es que la prueba de indicios es de naturaleza tal que no comporta fuerza suficiente sino mediante el conjunto que con ellos se forma. Por sí sólo cada uno es como débil hilo que no tiene tal vez resistencia para soportar un leve peso; pero unidos y trabados entre sí, se convierten como en fuerte y poderoso cable capaz de vencer grandes resistencias, y adquieren, por disposición expresa de la ley, valor de plena prueba (15 de marzo de 1893, M. P. Jesús Casas Rojas, G. J. año VIII, No. 389 (15 de mayo de 1893), página 205-2). " Citada en sentencia de la misma Corporación datada el 13 de septiembre de 2006, Radicación 23.251, Magistrado Ponente: Álvaro Orlando Pérez Pinzón.
} 
Por el contrario, en el proceso se demostró - en conjunto con la Fiscalía al hacer la estipulación probatoria No 5 -, la existencia del contrato, descartando una eventual elaboración del mismo por parte de la esposa de F.A.S.C., esta última quien a su vez narra la forma como se celebró el negocio jurídico en los mismos términos que lo hace el condenado.

En estas condiciones y frente a la carencia de certeza sobre la responsabilidad del sentenciado frente a las conductas punibles contra:

1. la eficaz y recta impartición de justicia y

2. la fe pública, cuando no se lograron establecer las reales circunstancias en que sucedieron los hechos, y particularmente que aquel haya conocido de manera antecedente la procedencia ilícita de la motocicleta hurtada en pretérita oportunidad, resultaba imperante absolver a F.A.S.C., por lo menos, en aplicación del principio in dubio pro reo.

Las argumentaciones de la juzgadora desconocen adicionalmente, que el tráfico de los negocios jurídicos se hace en muchas ocasiones, no intuite personae, a diferencia de lo que ocurría hace varios lustros o incluso en el sector rural donde todos se conocen con todos y es factible deducir quien es el vendedor y quien el comprador, conociendo incluso su entorno social y familiar. Por eso es dable predicar que F.A.S.C. no sabía quién era el vendedor de la motocicleta y que resultó engañado a través de artificios inteligentemente construidos por este último, incluso mediante la fachada de un nombre inexistente.

Oportuno en este sentido un pronunciamiento del Tribunal Superior de Bogotá -Sala Penal- ${ }^{42}$ :

En lo que atañe a las reglas de la experiencia, o juicios hipotéticos de contenido general provenientes de la experiencia o del sentido común, que peticiona el apelante se apliquen al caso en estudio para obtener la revocatoria de la providencia de alzada, corresponde contestarle que si bien prestan gran utilidad para obtener conocimiento, entratándose de permitir dictar sentencia condenatoria se necesita mucho más, pues no basta que puedan de determinada manera considerarse externalizadas y algo válidas, no, se exige mucho más, por ejemplo para caso como el en estudio, no es suficiente descubrirse a persona conduciendo automotor que exhibe placa falsa, se respalda su rodamiento con licencia de tránsito espuria y, se esconden estas irregularidades manteniendo cubierto el registro de "identicar " que señala en las ventanas el número original de la placa del carro, no, sino que se hace necesario escrutar mucho más hasta descubrir obran a la vez elementos materiales de prueba, evidencias o información cierta que permiten lograr convicción alguna, lo que fe aquí no ocurre, por tan ineficiente labor investigativa de la Fiscalía para respaldar su teoría del caso, y entonces el descubriendo de lo atrás expuesto no es capaz de entregar convencimiento de responsabilidad penal en el hecho. Es solo abstracción y entretenimiento lo que se brinda con tal postulación, o lo que es igual interpretación a su manera de un hecho por parte de sujeto procesal interesado y en últimas, así el sentido común invite a pensar que E.A.R. es Receptador, en el sistema acusatorio mucho más que informaciones generales en la etapa del Juicio Oral se demanda para condenar ..." (Resaltado fuera del texto)

\footnotetext{
${ }^{42}$ Providencia del 5 de octubre de 2005, Radicación: $110016000015200500104-02$ LMCT, Magistrado Ponente: Cesar Tulio Lozano Moreno
} 
En este sentido, las reglas de la experiencia, la lógica y la sana crítica de la funcionaria de instancia, conllevaron a condenar a un inocente, a un comprador de buena fe que resultó asaltado en la misma y que además de su perjuicio patrimonial, permaneció privado de la libertad por más de tres (3) años en los establecimientos penitenciario y carcelario "La Modelo" de Bogotá y "Picaleña" de Ibaguét ${ }^{3}$, en virtud de estos hechos, lo que no se compagina con los lineamientos del Estado Social y Democrático de Derecho.

\section{Desconocimiento del principio constitucional de la buena fe}

Establece el artículo 83 de la Constitución Política de Colombia:

Las actuaciones de los particulares y de las autoridades públicas deberán ceñirse a los postulados de la buena fe, la cual se presumirá en todas las gestiones que aquellos adelanten ante éstas.

En este caso, además de no tenerse en cuenta las pruebas de descargos, lo que per se, constituye una ilegalidad al omitir el contenido del artículo 404 del Código de Procedimiento Penal, el fallo no se corresponde con la Constitución, ya que en el proceso no se logró desacreditar la buena fe de F.A.S.C. Es más, la argumentación de la Jueza parece un fallo absolutorio en contra del vendedor de la motocicleta por el delito de estafa, con base en el criterio de imputación objetiva de autopuesta en peligro ${ }^{44}$ por parte del comprador ${ }^{45}$.

Refiere así la funcionaria: "se estaba exponiendo en un margen muy alto de probabilidad a no obtener jamás título de propiedad del vehículo sino a perder el monto de la plata y la moto entregada” ${ }^{36}$ ¿Será que esta ingenuidad debe ser castigada haciendo un uso acomodaticio del ius puniendi?

Establece la Jueza, como única contradicción entre lo dicho por F.A.S.C. y su esposa, la diferencia en cuanto a la percepción del origen del vendedor -huilense o costeño ${ }^{47}$ - (página 6 de la sentencia). ¿ Será esto suficiente para condenar? ¿No es factible confundirse en este aspecto? ¿No será usual ver que una persona del interior que se va para el eje cafetero o la costa atlántica terminé adquiriendo un acento similar al de las personas que allí viven?

\footnotetext{
${ }^{43}$ El 10 de abril de 2014, el Juzgado 1o de Ejecución de Penas y Medidas de Seguridad de Ibagué de Descongestión, concedió a favor de F.A.S.C. la prisión domiciliaria, acorde con lo normado en el artículo 38G del Código Penal.

${ }^{44}$ Cfr. COLOMBIA, Rama Judicial del Poder Público, Corte Suprema de justicia -Sala de Casación Penal -, sentencias 28693 (1006-08) y 29891 (08-10-08).

${ }^{45}$ Con base en el Código Penal Mexicano, se podría adoptar una decisión similar, en la medida que el artículo 400-I consagra la siguiente cláusula: "Si el que recibió la cosa en venta, prenda o bajo cualquier concepto, no tuvo conocimiento de la procedencia ilícita de aquélla, por no haber tomado las precauciones indispensables para asegurarse de que la persona de quien la recibió tenía derecho para disponer de ella, la pena se disminuirá hasta en una mitad" (Resaltado fuera del texto).

${ }^{46}$ Página 6 de la sentencia condenatoria.

${ }^{47}$ Los huilenses son nativos del interior del país y tienden a concatenar las palabras, con un acento cantado y lento, mientras que la denominación "costeños" atiende preponderantemente a los nativos de la costa caribe, con un acento un poco más rápido y similar al cubano, panameño o puertorriqueño.
} 


\section{Desconocimiento de la presunción de inocencia y el principio indubio pro reo}

De manera primigenia se abordarán algunos aspectos inherentes a este tema en abstracto ${ }^{48}$. En providencia del 20 de mayo de 2009, nuestro Tribunal de Casación ${ }^{49}$ manifestó que el principio de indubio pro reo consiste en lo siguiente:

Se recuerda que aquel postulado de contenidos desde luego sustanciales, es un estadio cognoscitivo en el que en la aprehensión de la realidad objetiva concurren fenómenos probatorios a favor y en contra, es decir, que afirman y a la vez niegan la existencia de la conducta material objeto de conocimiento penal de que se trate ( ...

Ante la presencia real de medios de convicción que tienen expresiones disímiles, como es de suyo se debe proceder a discernir hacia dónde se inclina la balanza de exclusiones, es decir, se deberá formular la pregunta y resolverla determinando si los contenidos probatorios de cargo tienen la capacidad, la fuerza necesaria de excluir de manera total o parcial a los descargos o a la inversa, bajo el entendido que el in dubio pro reo se consolida cuando las dudas surgidas de los elementos fácticos divergentes no se pueden disolver, en cuyo evento por principio universal corresponde por imperativo legal y constitucional resolverlas en todo evento a favor rei en salvaguarda de la presunción de inocencia ( ...).

Igualmente se ha reiterado a lo largo de la historia constitucional que el principio de la presunción de inocencia es uno de los derechos más importantes con los que cuenta una persona.

Para desvirtuar dicha presunción es necesario demostrar la responsabilidad con apoyo en pruebas debidamente controvertidas, dentro de un trámite que asegure la plenitud de las garantías procesales sobre la imparcialidad del juzgador y la íntegra observancia de las reglas predeterminadas en la ley para la indagación y esclarecimiento de los hechos, la práctica, discusión y valoración de las pruebas ${ }^{50}$.

Si la presunción de inocencia es un estado garantizado constitucional y legalmente a toda persona que se le inicie un proceso en nuestro territorio patrio, desprendiéndose la regla del in dubio pro reo en el sentido de que toda duda debe resolverse a favor del procesado y que al aplicarse por los funcionarios judiciales conduce indefectiblemente a la declaratoria de no responsabilidad, bien a través de la preclusión de la investigación o de la sentencia absolutoria, de ninguna manera puede equiparársele con la declaratoria de inocencia, habida cuenta que si la duda se entiende como carencia de certeza, deviene como lógica reflexión en los casos en que se considere, no la aseveración de que se juzgó a un inocente, sino la imposibilidad probatoria para que se dictara sentencia condenatoria ${ }^{51}$.

La presunción de inocencia también se encuentra ampliamente regulada en instrumentos internacionales. El artículo noveno de la Declaración de los Derechos del Hombre y del Ciudadano afirma que: "Todo hombre es considerado inocente hasta que ha sido convicto. Por lo tanto, siempre que su detención se haga indispensable, se ha de evitar por la ley cualquier rigor mayor del indispensable para asegurar su persona”.

La Declaración de los Derechos Humanos en su artículo onceavo, primer inciso, también ampara la presunción de inocencia de la siguiente manera: "Toda persona acusada de delito tiene derecho a que se presuma

\footnotetext{
${ }^{48}$ El desarrollo de estos aspectos es reproducido de HERNÁNDEZ (2012) pp. 163-164.

${ }^{49}$ COLOMBIA, Rama Judicial del Poder Público, Corte Suprema de Justicia - Sala de Casación Penal-, Radicación 31224, Magistrado Ponente: Yesid Ramírez Bastidas.

${ }^{50}$ BERNAL CUELLAR, Jaime y MONTEALEGRE LYNETT, Eduardo, Ob. Cit., pág 93. (Cita propia de la providencia).

${ }^{51}$ COLOMBIA, Rama Judicial del Poder Público, Corte Suprema de Justicia - Sala de Casación Penal -, providencia del 21 de enero de 2004, Radicación 16384. Magistrada Ponente: Marina Pulido de Barón.
} vol. 08, no. 04, Número Especial. Rio de Janeiro, 2015.pp. 2115-2138 
su inocencia mientras no se pruebe su culpabilidad, conforme a la ley y en juicio público en el que se le hayan asegurado todas las garantías necesarias para su defensa".

El Convenio de Roma para la protección de los Derechos Humanos y Libertad Fundamentales la consagra en su artículo segundo, como parte integrante del derecho al proceso equitativo diciendo que: "Toda persona acusada de una infracción se presume inocente hasta que la culpabilidad haya sido legalmente declarada"

Lo mismo sucede con el Pacto Internacional de los Derechos Civiles y Políticos en su artículo catorce, numeral segundo: "Toda persona acusada de un delito tiene derecho a que se presuma su inocencia mientras no se pruebe su culpabilidad conforme a la ley".

Existiendo entonces duda razonable sobre la responsabilidad penal, deberá en todo caso el Juez de Conocimiento proferir un fallo de carácter absolutorio, so pena de vulnerar este derecho ampliamente protegido nacional e internacionalmente.

Ahora bien, a Record 02:06:20 - 02:06:32 (audiencia de juicio oral) la Jueza expresa "Me queda una duda, ¿qué pasaría con los papeles del traspaso de la moto objeto de permuta?" ¿Logró la funcionaria disipar esa duda? o ¿simplemente optó por ignorarla? Otra duda de la Jueza consiste en la fecha del contrato, a pesar de existir las declaraciones de F.A.S.C. y su esposa, sobre la realización del mismo y por supuesto, la estipulación probatoria No. 5 tantas veces citada y tantas veces omitida por la funcionaria.

Supera arbitrariamente la duda sobre la presencia de F.A.S.C. en el Centro Comercial "Hayuelos" a pesar de las manifestaciones hechas por aquel y su esposa e incluso lo manifestado por el investigador del C.T.I., que dentro de las labores de investigación solicitó un registro filmico, que por corresponder a un back up del sistema de vigilancia del lugar, no contiene las imágenes requeridas para superar dicha duda.

En consecuencia, por respeto a la presunción constitucional de inocencia ${ }^{52}$, debe decirse que efectivamente la carga de la prueba en el proceso penal está en cabeza del Estado -a pesar de lo considerado por la funcionaria al hacer la respectiva motivación del sentido del fallo, una vez culminado el juicio oral- y es a éste a quien le corresponde demostrar la responsabilidad penal del acusado mediante los diferentes medios probatorios recaudados y debatidos en juicio, lo cual no se logró efectivamente para proferir un fallo adverso, no pudiéndose establecer la responsabilidad del acusado en los hechos materia de investigación.

Por todo lo anterior se considera que se encontraba incólume el apotegma de la presunción de inocencia, comoquiera que probatoriamente se echa de menos el dolo como presupuesto de responsabilidad y la consiguiente imposición de la pena, definida como la conducta externa de un sujeto, que pudiendo obrar de otro modo y siendo capaz de comprender el hecho, voluntariamente incurre en el comportamiento, merecedor de

\footnotetext{
${ }^{52}$ Artículo 29 de la Constitución Política en concordancia con el artículo 11 de la Declaración Universal de los Derechos del Hombre.
} 
reproche punitivo, conociendo los hechos constitutivos de la infracción penal y queriendo su realización o cuando habiendo previsto la conducta como probable, su no producción se deja librada al azar (dolo eventual).

Confrontados los escasos medios de prueba obrantes en el proceso y que fueron analizados en detalle en el presente artículo de reflexión, lo mínimo que suscita en la mente del lector - pasado por alto por la juzgadora, quien era la obligada a encontrar la verdad real, averiguando con igual celo las circunstancias que demuestren la responsabilidad o inocencia del procesado, garantizando las prerrogativas tanto de aquel como de la sociedad en general -, es que el proceso empuja el conocimiento hacia la incertidumbre propia del estadio mental de la duda.

Adicionalmente, es sabido que al juzgador le está vedado proferir sentencia de condena sobre conjeturas o probabilidades, requiere de un conocimiento cierto, real, verídico - certeza racional - y cuando la duda no es superable como ocurre en el presente caso, corresponde inclinarse por el principio universal de la presunción de inocencia y reconocerla a favor del procesado como lo estipula la Constitución Política -artículo 29-, y reafirma el Código de Procedimiento Penal en su norma rectora -artículo 70-, como bien lo tiene dicho doctrina de la Corte Constitucional:

La presunción de inocencia en nuestro ordenamiento jurídico adquiere el rango de derecho fundamental, por virtud del cual, el acusado no está obligado a presentar prueba alguna que demuestre su inocencia y por el contrario ordena a las autoridades judiciales competentes la demostración de la culpabilidad del agente. Este derecho acompaña al acusado desde el inicio de la acción penal (por denuncia, querella o de oficio) hasta el fallo o veredicto definitivo y firme de culpabilidad, y exige para ser desvirtuada la convicción o certeza, más allá de una duda razonable, basada en el material probatorio que establezca los elementos del delito y la conexión del mismo con el acusado. Esto es así, porque ante la duda en la realización del hecho y en la culpabilidad del agente, se debe aplicar el principio del in dubio pro reo, según el cual toda duda debe resolverse en favor del acusado. ${ }^{53}$

En el mismo sentido, la Sala Penal del Tribunal Superior de Bogotá:

Es entonces cuando a esta Instancia, a efecto de respaldar la decisión a tomar, esto es, la de confirmación de la sentencia apelada, tal como lo anunciara en el acápite inmediatamente anterior, le compete precisar que no por el hecho de obedecer el sistema acusatorio a un proceso adversarial, relevada queda la Fiscalía General de la Nación, una vez iniciada formal investigación penal, de realizar una investigación completa y así de llevada a Juicio Oral, poder sustentar la acusación con seriedad y juicio persuadiendo satisfactoriamente al Juez sobre la autoría y responsabilidad penal de investigado, con elementos materiales probatorios, evidencias, etc., lo que solo es posible alcanzar adelantada actividad investigativa intensa con la colaboración de sus investigadores o policía judicial, actividad que huelga decir debe ser mucho más que la a desarrollar por la defensa, pues como se infiere razonable de lo atrás expuesto es ella quien debe satisfacer la carga de la prueba que el principio de la presunción de inocencia le impone, en tanto que a ésta le basta con sembrar una duda, lo que es suficiente para conseguir la absolución, entendiendo como duda el crear un serio vacío en la teoría del caso de la Fiscalía y entonces para introducirlo no le hace falta cumplir una

${ }^{53}$ COLOMBIA, Rama Judicial del Poder Público, Corte Constitucional, Sentencia C-416/02 Magistrada Ponente: Clara Inés Vargas Hernández 
investigación muy amplia. En síntesis, para que resulte persuadido el Juez sobre la autoría y responsabilidad penal del imputado, la acusadora debe investigar más que la defensa, porque, repetimos, tiene la carga de la prueba más allá de duda razonable y en este caso no cumplió en nada tal tarea frente al tema de la tipicidad del hecho examinada a la luz del dolo o conciencia del reo de que el automotor que conducía tenía origen ilícito, que fue lo que le imposibilitó al Juez obtener convicción más allá de toda duda razonable como para condenar al señor E.A.R. ${ }^{54}$

El delito de receptación exige para su configuración que el agente realice alguno de los verbos rectores pero con el conocimiento de que los bienes provengan de la comisión de otra conducta punible, pero en el caso del procesado no se probó, más allá de toda duda razonable, que conocía del origen ilícito de las cosas, pues la investigación a penas dejó ese supuesto como una hipótesis probable, permitiendo una duda que debe ser resuelta a su favor y que determina la revocatoria de la condena para en su lugar absolverlo del cargo formulado en la acusación. ${ }^{55}$

En suma, en el presente proceso no se logró demostrar el dolo de F.A.S.C. en la conducta punible judicializada, profiriéndose un fallo de condena en contravía de los mandatos constitucionales y legales.

Por último, no se podría concluir este texto, sin resolver un cuestionamiento, que indudablemente debe estar latente a estas alturas del relato: ¿Por qué F.A.S.C. no ejerció su derecho a apelar la sentencia condenatoria ${ }^{56}$ ? Y la respuesta probablemente se tornará más confusa: F.A.S.C., a través de su defensor pro bono, apeló la sentencia, correspondiendo por reparto el caso (17 de febrero de 2012), a un magistrado del Tribunal Superior de Bogotá -Sala Penal-. Luego de transcurrido más de un año y tras solicitarse celeridad en el registro de proyecto de fallo, sin obtener este cometido, F.A.S.C. decide desistir del recurso ${ }^{57}$, con el objetivo de obtener la ejecutoria de la sentencia para poder así, redimir pena al interior de la Cárcel y solicitar la concesión de algún subrogado ${ }^{58}$ ante los

\footnotetext{
${ }^{54}$ Providencia del 5 de octubre de 2005, Radicación: $110016000015200500104-02$, Magistrado Ponente: Cesar Tulio Lozano Moreno

${ }^{55}$ Sentencia del 24 de noviembre de 2005, Radicación: 110016000049200502195 01, Magistrado Ponente: Fernando Adolfo Pareja Reinemer

56 "Sin duda, como norma integrativa del debido proceso, el artículo 31 C.N. consagra el principio de la doble instancia, en el sentido de que toda sentencia judicial podrá ser apelada o consultada, salvo las excepciones que consagre la ley. Principio este que garantiza el ejercicio del derecho de defensa y de contradicción, integrantes del denominado debido proceso. En materia penal, resulta de singular importancia que el superior jerárquico del funcionario encargado de tomar una decisión en primera instancia, pueda libremente estudiar y evaluar las argumentaciones expuestas y llegar, por tanto, al convencimiento de que la determinación adoptada se fundamentó en suficientes bases fácticas y legales, o que, por el contrario, desconoció pruebas, hechos o consideraciones jurídicas que ameritaban un razonamiento y un juicio diferente" BERNAL y MONTEALEGRE (2004) p.375.

${ }^{57}$ El desistimiento es aceptado mediante auto del 27 de junio de 2013.

${ }^{58}$ La legislación penal colombiana consagra algunos mecanismos sustitutivos de la pena de prisión (subrogados penales) que operan como dispositivos que permiten cambiar o mutar la internación en establecimiento penitenciario por la alternativa de no purgar la pena, purgarla en el lugar de residencia del condenado/condenada o purgar un tiempo determinado en prisión y poder salir de ella en un lapso inferior a la pena definitiva impuesta. VELÁSQUEZ (2009) p. 1155. Tradicionalmente, dentro de la cultura jurídico penal, se han concebido como subrogados penales: 1) la condena de ejecución condicional (hoy suspensión condicional de la ejecución de la pena) y 2) la libertad condicional (COLOMBIA, Rama Judicial del Poder Público, Corte Constitucional, Sentencia C-679/98, Magistrado ponente: Carlos Gaviria Díaz). Sin embargo, dentro de esta tipología también puede consagrase la prisión domiciliaria (COLOMBIA, Rama Judicial del Poder Público, Corte Suprema de Justicia - Sala de Casación Penal -, providencias del 8 de julio de 2009, Radicación 31531, Magistrado Ponente: Yesid Ramírez Bastidas y del 28 de octubre de 2009, Radicación 31568, Magistrado Ponente: Alfredo Gómez Quintero) y una modalidad de prisión domiciliaria establecida por el legislador del año 2000, cuyos beneficiarios son todas las personas que ostenten la calidad de madre o padre (COLOMBIA, Rama Judicial del Poder Público, Corte Constitucional, Sentencia C-184/03, Magistrado Ponente: Manuel José Cepeda Espinosa), vol. 08, n. 04, Número Especial. Rio de Janeiro, 2015.pp. 2115-2138 
Juzgados de Ejecución de Penas y Medidas de Seguridad. Adicionalmente F.A.S.C. fue informado por sus compañeros de reclusión, que la apelación podía demorarse más, que incluso el tiempo de la pena privativa de la libertad. Todo esto lo motivó al desistimiento de la alzada y a la convalidación de una ejecutoria injusta.

\section{CONCLUSIÓN}

En este caso se demostró la inocencia de F.A.S.C. frente a las conductas contra la eficaz y recta impartición de justicia y contra la fe pública por las cuales fue convocado a juicio. Se acreditó su calidad de comprador de buena fe e incluso su condición de víctima en el negocio jurídico vinculado a la motocicleta referenciada. No obstante, en caso de no ser compartido este criterio, es cuestionable el hecho que no se logró dispar de manera indubitable, las dudas relacionadas con la responsabilidad de aquel, debiendo resultar beneficiado por los parámetros del bloque de constitucionalidad inherentes al indubio pro reo. Este principio, que debe ser aplicado de manera prevalente en toda actuación penal, dentro de la práctica judicial es modificado para edificar una presunción de responsabilidad, incongruente con los lineamientos de un Estado Social y Democrático de Derecho.

Con adición a la errada valoración probatoria de la jueza, analizada en detalle en este texto, se suma la imposibilidad de acceso a la justicia para obtener la resolución del recurso de apelación (falta de celeridad) y las deficientes condiciones del sistema penitenciario colombiano, que en ocasiones conllevan no solo al resultado aquí expuesto, sino incluso a la aceptación de los cargos (plea bargaining) endilgados por la Fiscalía General de la Nación, con el único objetivo de reducir el tiempo de privación de la libertad o la obtención de la libertad, con independencia de la condena en su contra. Este incentivo, ciertamente se torna peligroso y puede atentar eventualmente contra los derechos del procesado que no es responsable penalmente, prefiriendo una condena corta y la consecuente excarcelación o como en el caso objeto de estudio, optar por desistir de la garantía de la doble instancia, en procura de obtener subrogados penales que le permitan descontar la pena extramuros.

Casos como este permiten observar que tras la entrada en vigencia del sistema penal de corte acusatorio, la Judicatura le rinde un mayor culto a la técnica y "las capacidades histriónicas de los intervinientes", dejando relegada a la dogmática penal, incluso en algo básico y elemental: la comprobación del dolo en un delito que no admite la culpa ni la preterintención.

Por esto, no se puede asimilar la figura del Juez penal a la de un Juez de condena, debiéndose garantizar en todo caso, los derechos de los ciudadanos sometidos a las miserias del proceso penal -utilizando los términos de Carnelutti -, quien en esta noble labor de administrar justicia debe ceder ante los prejuicios personales y las

cabeza de familia (COLOMBIA, Rama Judicial del Poder Público, Corte Constitucional, Sentencia T-483/12, Magistrado Ponente: Gabriel Eduardo Mendoza Martelo). 
presiones sociales, prevalido de una visión garantista, que en términos de Voltaire se traducen perfectamente en la siguiente frase: "Es mejor exponerse a absolver a un hombre culpable que condenar a un inocente".

\title{
RECEIVING AND CRIMINAL DOGMATIC: CASE STUDY IN THE CONTEXT OF THE COLOMBIAN CRIMINAL SYSTEM
}

\begin{abstract}
This paper discusses a conviction for the offense of receiving ${ }^{59}$, issued by the Circuit Criminal Court 30 of Bogotá (Colombia). This conviction follows the adversarial system provided in the Legislative Act 03 of 2002 and Act 906 of 2004. Through a deconstruction process, I show (i) the arguments that were taken into account by the judicial office to make a decision against the interests of the sentenced person, and (ii) possible flaws, based on the guidelines of the criminal dogma fault point, the improper evidence assessment, and the failure of the constitutional principles underlying criminal proceedings.
\end{abstract}

Keywords: Receiving, adversarial system, judgment, testing, criminal dogma, due process.

\section{BIBLIOGRAFÍA CITADA}

ARENAS, Jorge (1996). Pruebas Penales. (Bogotá, Doctrina y Ley, segunda edición).

BAYTELMAN, Andrés y DUCE, Mauricio (2005). Litigación penal. Juicio oral y prueba. (México, D.F., Fondo de Cultura Económica, primera edición).

BERNAL, Jaime y MONTEALEGRE, Eduardo (2004). El proceso penal. Fundamentos constitucionales del nuevo sistema acusatorio. Tomo I. (Bogotá, Universidad Externado de Colombia, quinta edición).

BERNATE, Francisco (2005). "El principio de oralidad”, en Sistema Penal Acusatorio (Bogotá, Universidad del Rosario y Dike, primera edición) pp. 61-83.

BUSTOS, Juan J. (1986). Manual de derecho penal. Parte especial. (Barcelona, Ariel, primera edición).

BUSTOS, Juan J. y HORMAZÁBAL, Hernán (2004). Nuevo sistema de derecho penal. (Madrid, Trotta, segunda edición).

HERNÁNDEZ, Norberto (2012). "De los impedimentos y las recusaciones en el marco del sistema de enjuiciamiento penal colombiano”. Revista Diálogos de Saberes. № 36. (Bogotá, Universidad Libre) pp. 157-172

HERNÁNDEZ, Norberto (2010). "Aproximación a la casación penal desde un análisis principialístico". Revista de derecho público. № 25. (Bogotá, Universidad de los Andes) pp. 1-26. 
MARTÍNEZ, Gilberto (2006). Procedimiento penal colombiano. Sistema penal acusatorio. (Bogotá, Temis, decimotercera edición).

PABÓN, Pedro (2011). Manual de derecho penal. Tomo II, Parte especial. (Bogotá, Doctrina y ley, octava edición).

PARRA, Jairo (2009). Manual de derecho probatorio. (Bogotá, Librería Ediciones del Profesional, décima séptima edición).

POSADA, Ricardo (2008). "El dolo en el Código Penal de 2000", en: Posada, Ricardo (Coord.), Temas de derecho penal. (Bogotá, Universidad de los Andes y Temis, primera edición) pp. 1-73.

REYES, Alfonso (1989). Tipicidad. (Bogotá, Temis, sexta edición).

VELASQUEZ, Fernando (2009). Derecho penal, parte general. (Medellín, Comlibros, cuarta edición)

\section{Normas citadas}

ALEMANIA, Código Penal, (Trad. Claudia López, Bogotá, Universidad Externado de Colombia).

CHILE, Congreso Nacional, Código Penal.

COLOMBIA, Asamblea Nacional Constituyente, Constitución Política de 1991.

Congreso de la República, Acto legislativo 03 de 2002. Sistema mixto con tendencia inquisitivo.

Congreso de la República, Ley 599 de 2000. Código Penal

Congreso de la República, Ley 600 de 2000. Código de Procedimiento Penal (Sistema mixto con tendencia inquisitivo)

Congreso de la República, Ley 906 de 2000. Código de Procedimiento Penal (Sistema con tendencia acusatorio)

FRANCIA, Código Penal, (Trad. Jose Luis de la Cuesta Arzamendi). Disponible en: http://perso.unifr.ch/derechopenal/assets/files/legislacion/1_20080616_45.pdf

MEXICO, Cámara de Diputados del Congreso de la Unión, Código Penal Federal.

\section{Jurisprudencia citada}

COLOMBIA, Rama Judicial del Poder Público, Corte Constitucional, sentencia C-679/98, Magistrado Ponente: Carlos Gaviria Díaz

Rama Judicial del Poder Público, Corte Constitucional, sentencia C-416/02, Magistrada Ponente: Clara Inés Vargas Hernández

Rama Judicial del Poder Público, Corte Constitucional, sentencia C-454/06, Magistrado Ponente: Jaime Córdoba Triviño

Rama Judicial del Poder Público, Corte Constitucional, sentencia C-184/03, Magistrado Ponente: Manuel José Cepeda Vargas

Rama Judicial del Poder Público, Corte Constitucional, sentencia T-483/12, Magistrado Ponente: Gabriel Eduardo Mendoza Martelo 
Rama Judicial del Poder Público, Corte Suprema de Justicia -Sala de Casación Penal-, providencia del 26 de mayo de 1971, Magistrado Ponente: Luis Carlos Pérez.

Rama Judicial del Poder Público, Corte Suprema de Justicia -Sala de Casación Penal-, providencia del 4 de junio de 1982, Radicación: 26836, Magistrado Ponente: Luis Enrique Romero Soto.

Rama Judicial del Poder Público, Corte Suprema de Justicia -Sala de Casación Penal-, providencia del 27 de julio de 1982, Magistrado Ponente: Alfonso Reyes Echandía.

Rama Judicial del Poder Público, Corte Suprema de Justicia - Sala de Casación Penal -, providencia del 21 de enero de 2004, Radicación 16384. Magistrada Ponente: Marina Pulido de Barón.

Rama Judicial del Poder Público, Corte Suprema de Justicia -Sala de Casación Penal-, providencia del 30 de marzo de 2006, Radicación 24468, Magistrado Ponente: Edgar Lombana Trujillo

Rama Judicial del Poder Público, Corte Suprema de Justicia -Sala de Casación Penal-, sentencia del 13 de septiembre de 2006, Radicación 23.251, Magistrado Ponente: Álvaro Orlando Pérez Pinzón

Rama Judicial del Poder Público, Corte Suprema de Justicia -Sala de Casación Penal-, providencia del 26 de octubre de 2007, Radicación 27608, Magistrado Ponente: Sigifredo Espinosa Pérez.

Rama Judicial del Poder Público, Corte Suprema de Justicia -Sala de Casación Penal-, providencia del 6 de septiembre de 2007, Radicación 24786, Magistrado Ponente: Yesid Ramírez Bastidas.

Rama Judicial del Poder Público, Corte Suprema de Justicia -Sala de Casación Penal-, providencia del 17 de septiembre de 2007, Radicación 27336, Magistrado Ponente: Jorge Luis Quintero Milanés y Augusto J. Ibáñez Guzmán.

Rama Judicial del Poder Público -Sala de Casación Penal-, sentencia del 5 de diciembre de 2007, Radicación 28432, Magistrada Ponente: Maria del Rosario González de Lemos.

Rama Judicial del Poder Público, Corte Suprema de Justicia - Sala de Casación Penal -, providencia del 8 de julio de 2009, Radicación 31531, Magistrado Ponente: Yesid Ramírez Bastidas

Rama Judicial del Poder Público, Corte Suprema de Justicia - Sala de Casación Penal -, providencia del 28 de octubre de 2009, Radicación 31568, Magistrado Ponente: Alfredo Gómez Quintero)

Rama Judicial del Poder Público, Corte Suprema de Justicia - Sala de Casación Penal-, providencia del 17 de agosto de 2011, Radicación 35978, Magistrado Ponente: Fernando Alberto Castro Caballero.

Rama Judicial del Poder Público, Corte Suprema de Justicia -Sala de Casación Penal-, providencia del 6 de febrero de 2013, Radicación 38975, Magistrado Ponente: José Luis Barceló Camacho.

Rama Judicial del Poder Público, Juzgado 30 Penal del Circuito, sentencia del 14 de diciembre de 2011, Radicación: 110016000017201101928, Número interno: 142952, Jueza: Marcela Roldán Zerda

Rama judicial del Poder Público, Tribunal Superior de Bogotá - Sala Penal -, providencia del 9 de noviembre de 2005, Radicación: S 040 -2005- 02208 - 01, Magistrada Ponente: María Del Rosario González De Lemos

Rama judicial del Poder Público, Tribunal Superior de Bogotá -Sala Penal -, sentencia del 24 de noviembre de 2005, Radicación: 110016000049200502195 01, Magistrado Ponente: Fernando Adolfo Pareja Reinemer

Rama judicial del Poder Público, Tribunal Superior de Bogotá -Sala Penal -, providencia del 5 de octubre de 2005, Radicación: 110016000015200500104-02, Magistrado Ponente: Cesar Tulio Lozano Moreno

Rama judicial del Poder Público, Tribunal Superior de Bogotá -Sala Penal -, providencia del 21 de marzo de 2006, Radicación: 1100160000132005096801, Magistrado Ponente: Alberto González Gómez

Rama judicial del Poder Público, Tribunal Superior de Bogotá -Sala Penal -, providencia del 27 de febrero de 2012, radicación: 11001600001720110192801, M.P. Javier Armando Fletscher Plazas

Rama judicial del Poder Público, Tribunal Superior de Bogotá -Sala Penal -, providencia del 27 de junio de 2013, radicación: 11001600001720110192801 , M.P. Javier Armando Fletscher Plazas

Rama Judicial del Poder Público, Tribunal Superior de Medellín -Sala Penal-, sentencia del 7 de junio de 2011, Radicación 05001-60-00206-2010-58044, Magistrado Ponente: Pio Nicolás Jaramillo Marín. 
CHILE, Poder Judicial, Juzgado de Letras y Garantía de Pucón, sentencia del 6 de junio de 2003, Juez: Marcela Alejandra Robles Sanguinetti.

Trabalho enviado em 02 de fevereiro de 2015.

Aceito em 24 de março de 2015. 